\title{
Comparison of Myeloablative Versus Reduced-Intensity Conditioning Regimens for Allogeneic Hematopoietic Stem Cell Transplantation in Acute Myeloid Leukemia: A Cohort Study
}

\author{
Allojenik Hematopoetik Kök Hücre Nakli Yapılan Akut Myeloid Lösemili Hastalarda \\ Myeloablatif Hazırlama Rejimi ile Indirgenmiş Yoğunlukta Hazırlama Rejiminin \\ Karşılaştırılması: Kohort Çalışması
}

\footnotetext{
(D) Rafiye Çiftçiler, (D) Hakan Göker, (D) Haluk Demiroğlu, (D) Elifcan Aladağ, (D) Salih Aksu, (D) ibrahim Celalettin Haznedaroğlu, (D) Nilgün Sayınalp, (D) Osman Özcebe, (D) Fatma Tekin, (D) Yahya Büyükaşık
}

Hacettepe University Faculty of Medicine, Department of Hematology, Ankara, Turkey

\section{Abstract}

Objective: Allogeneic hematopoietic stem cell transplantation (HSCT) is an effective treatment modality for a variety of malignant and non-malignant hematologic disorders. Myeloablative conditioning (MAC) and reduced-intensity conditioning (RIC) regimens could have different clinical outcomes. This purpose of this study was to assess the long-term outcome of MAC versus RIC regimens in patients with acute myeloid leukemia (AML) undergoing allogeneic HSCT.

Materials and Methods: We retrospectively compared long-term outcomes with MAC and RIC regimens in patients with AML who underwent allo-HSCT at our tertiary transplantation center.

Results: We analyzed survival outcomes after MAC-HSCT versus RICHSCT among 107 adult patients with AML diagnosed from 2001 through 2017. Of those, 44 patients underwent a MAC regimen, whereas 63 patients received a RIC regimen. The median follow-up time was 37 months (range: $6-210$ ) for the entire group. The 3-year overall survival (OS) for RIC and MAC patients was 67\% and 60\%, respectively ( $p>0.05$ ). The 3-year progression-free survival (PFS) for RIC and MAC patients was $88 \%$ and $77 \%$. In multivariate analysis, the type of conditioning regimen (RIC vs. MAC) did not influence PFS $(p=0.24)$. Acute graft-versus-host disease (GVHD) was seen in five of the RIC patients and 9 of the MAC patients. Chronic GVHD was seen in 16 of the RIC patients and 6 of the MAC patients. There was no significant difference between the two groups in terms of acute GVHD ( $p=0.089)$, but there was a significant difference between the two groups in terms of chronic GVHD ( $p=0.03)$.

Conclusion: This retrospective analysis confirmed that MAC and RIC regimens had a consistently equivalent rate of OS and PFS in AML patients who underwent allo-HSCT. The choice of MAC versus RIC conditioning regimen might be decided on the basis of patient and disease characteristics.

Keywords: Acute myeloid leukemia, Allogeneic hematopoietic stem cell transplantation, Regimen
Öz

Amaç: Allojenik hematopoetik kök hücre nakli (AHKHN), çeşitli malign ve malign olmayan hematolojik hastalıklar için etkili bir tedavi yöntemidir. Myeloablatif hazırlama rejimi (MHR) ve düşük yoğunlukta hazırlama rejimleri farklı klinik sonuçlara sahip olabilir. Bu çalışmanın amacı, AHKHN uygulanan akut myeloid lösemili (AML) hastalarda myeloablatif ve indirgenmiş yoğunlukta hazırlama rejimlerinin uzun dönem sonuçlarını değerlendirmektir.

Gereç ve Yöntemler: Üçüncü basamak transplantasyon merkezimizde myeloablatif ve indirgenmiş yoğunlukta hazırlama rejimleri ile AHKHN uygulanan AML'li hastalarda uzun dönem sonuçları geriye dönük olarak karşılaştırıldı.

Bulgular: 2001-2017 yılları arasında AML tanısı almış 107 erişkin hastada AHKHN sonrasında sağkalım sonuçları analiz edildi. Ortanca takip süresi tüm hastalar için 37 aydı (6-210). İndirgenmiş yoğunlukta ve MHR alan hastalar için 3 yıllık genel sağkalım (GS), sırasıyla \%67 ve $\% 60$ saptandı $(p>0,05)$. Indirgenmiş yoğunlukta ve MHR alan hastalar için 3 yıllık progresyonsuz sağkalım (PS) \%88 ve \%77 olarak saptandı. Multivariate analizde hazırlama rejiminin PS'yi etkilemediği gözlendi $(p=0,24)$. Indirgenmiş yoğunlukta hazırlama rejimi alan hastaların 5 'inde ve MHR alan hastaların 9'unda akut graft-versus-host hastalığı (GVHH) gözlendi. İndirgenmiş yoğunlukta hazırlama rejimi alan hastaların 16'sında ve MHR alan hastaların 6'sında kronik GVHH gözlendi. İki grup arasında akut GVHH açısından anlamlı fark yoktu $(p=0,089)$, ancak iki grup arasında kronik GVHH açısından anlamlı fark vardı $(p=0,03)$.

Sonuç: Bu retrospektif analizde, indirgenmiş yoğunlukta yada MHR rejimi ile AHKHN uygulanan AML hastalarında GS ve PS arasında anlamlı farklılık saptanmadı. AHKHN öncesi hazırlama rejimine hastaya ve hastalığın özelliğine göre karar verilmelidir.

Anahtar Sözcükler: Akut myeloid lösemi, Allojenik hematopoetik kök hücre nakli, Rejim

๑Copyright 2019 by Turkish Society of Hematology

Turkish Journal of Hematology, Published by Galenos Publishing House

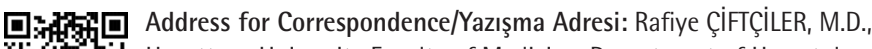

Hacettepe University Faculty of Medicine, Department of Hematology, Ankara, Turkey

Received/Geliş tarihi: June 26, 2018

Phone : +905055831798

E-mail : rafiyesarigul@gmail.com ORCID-ID: orcid.org/0000-0001-5687-8531 


\section{Introduction}

Allogeneic hematopoietic stem cell transplantation (allo-HSCT) is a therapy with curative potential in patients with acute myeloid leukemia (AML) as well as other hematologic neoplastic disorders [1]. The therapeutic outcome of allo-HSCT lies in the balance of the risk of the myelotoxic conditioning regimen before allo-HSCT and an immunological graft-versus-leukemia effect of donor cell reactivity against host malignant cells. In AML patients, complete remission (CR) can be achieved with induction chemotherapy in almost $65 \%$ of cases. However, the 5 -year progression-free survival (PFS) rate is usually lower than $50 \%$ with conventional chemotherapy $[2,3,4]$. Recipient age, disease status at the time of allo-HSCT, donor type, cytogenetics of the AML patients, and hematopoietic cell transplantation (HCT)-comorbidity index contribute to the outcome variables in both myeloablative conditioning (MAC) and reduced-intensity conditioning (RIC) [5]. RIC regimens could decrease toxicities related to allo-HSCT with an acceptable relapse rate. Therefore, RIC has extended the approach of allo-HSCT in AML to include patients who are not eligible candidates for standard allo-HSCT because of their advanced age and/or comorbidities $[6,7,8,9]$. Despite the common use of RIC allo-HSCT for the treatment of AML patients, few randomized clinical trials have compared the survival outcomes between RIC and MAC in AML patients for allo-HSCT $[10,11,12]$. Furthermore, several previous studies comparing the survival outcomes of RIC and MAC allo-HSCT in AML patients have reported contradictory results. Thus, we retrospectively compared long-term outcomes of AML patients who received MAC and RIC regimens for allo-HSCT at our tertiary transplantation center. Additionally, we analyzed the patient characteristics, disease and transplantation characteristics, and incidences of acute and chronic graft-versus-host disease (GVHD). This is a retrospective study. It gives insight about the almost equivalent efficacy of RIC allo-HSCT in comparison to MAC allo-HSCT.

\section{Materials and Methods}

\section{Study Design, Data Collection, and Supportive Care}

Our study was performed in a retrospective manner. One hundred and seven patients with AML who received allo-HSCT in our tertiary transplant center between the years of 2001 and 2017 were evaluated. RIC and MAC patients were transplanted during the same period. Patients who had intermediate or adverse cytogenetic risk scores according to the European LeukemiaNet classification [13] and who failed the first induction chemotherapy or relapsed after complete remission underwent allo-HSCT. Patients without $\mathrm{t}(8 ; 21)$, inv $16, \mathrm{t}(15 ; 17)$, and $t(2 ; 5)$ received allo-HSCT. Patients who had a performance status between 0 and 2 by Eastern Cooperative Oncology Group (ECOG) criteria also underwent allo-HSCT [14]. Patients received antiviral prophylaxis against herpes simplex and varicella zoster, and prophylaxis against Pneumocystis jirovecii, for 6 months after allo-HSCT. As a result of application standards of the hospitals of our tertiary center, it was confirmed from patient records that all studied patients gave informed consent at the time of admission to the hospital and before the administration of allo-HSCT.

\section{Patient, Disease, and Transplant Characteristics}

In this study, there were 59 males and 48 females with a median age of 45 (range: 20-66) years at the time of transplantation. Stem cells were obtained from HLA-matched related donors. Donor peripheral blood stem cells were mobilized by granulocyte colony-stimulating factor. Peripheral blood stem cells were used for all patients who underwent allo-HSCT. The indications for selecting the RIC regimen were as follows: inadequate liver, kidney, or cardiac functions (defined as serum transaminase levels $>3$ times the upper limit of normal reference value, total bilirubin $>2 \mathrm{mg} / \mathrm{dL}$, creatinine clearance $<60 \mathrm{~mL} / \mathrm{min}$, left ventricular ejection fraction $<50 \%$ ); serious fungal infection before allo-HSCT; ECOG performance status of $>2$; and the patient's refusal of the MAC regimen before allo-HSCT.

\section{Conditioning Regimens}

Mainly the busulfan, fludarabine, and antithymocyte globulin (BU/FLU/ATG) RIC regimen was preferred. An intravenous BU/FLU/ATG regimen was applied for 63 patients, consisting of intravenous (i.v.) fludarabine at $50 \mathrm{mg} / \mathrm{kg}$ over $30 \mathrm{~min}$ for 6 consecutive days, $9 \mathrm{mg} / \mathrm{kg}$ or less oral busulfan (or intravenous equivalent q6h for 2 consecutive days), and ATG at $5 \mathrm{mg} / \mathrm{kg} / \mathrm{day}$ for $3 \pm 1$ consecutive days [15]. Phenytoin was given to prevent busulfan-induced seizures. The preferred MAC regimen was i.v. cyclophosphamide at $60 \mathrm{mg} / \mathrm{kg}$ daily for 2 days and busulfan at $>8 \mathrm{mg} / \mathrm{kg}$ orally (or intravenous equivalent more than $0.8 \mathrm{mg} / \mathrm{kg}$ i.v. infusion q6h) for 4 days [16]. The other myeloablative conditioning regimen was i.v. BU at $>0.8 \mathrm{mg} / \mathrm{kg}$ q6h for 4 days, plus i.v. FLU with ATG.

\section{GVHD Prophylaxis and Grading}

All patients received standard cyclosporine A (CsA) and methotrexate therapy for GVHD prophylaxis. Usually, tapering of immune suppression was initiated at 3 months after alloHSCT in the absence of acute or chronic GVHD, with the aim of stopping it by approximately 6 months after HSCT. Acute and chronic GVHD were graded according to the related consensus criteria $[17,18]$.

\section{Statistical Analysis}

SPSS 25 (IBM Corp., Armonk, NY, USA) was used to perform statistical analyses. The variables were investigated using visual (histograms, probability plots) and analytical methods (Kolmogorov-Smirnov/Shapiro-Wilk test) to determine whether they were normally distributed or not. Statistical 
comparisons were made using chi-square tests for categorical data. The Student t-test (for two independent samples) was used for comparison of continuous numerical data. Survival analyses were made using the Kaplan-Meier test. Multivariate analyses of predictors of survival were performed using the Cox regression test. Parameters with $p \leq 0.20$ in univariate tests were included in the multivariate analysis, and $p<0.05$ was considered to indicate statistical significance. Cumulative incidences of relapse and non-relapse mortality were calculated by means of the statistical software environment $R$ version 2.15.2 [19].

\section{Ethics}

All of the ethical considerations were strictly followed in accordance with the 1964 Helsinki Declaration in the Hacettepe University Faculty of Medicine. As standard care/ action of the hospitals of the Hacettepe University Faculty of Medicine, it has been recognized from the patient records that all of the studied patients gave informed consent at the time of admission to the hospital and before the administration of chemotherapy and other relevant diagnostic/therapeutic standards of care.

\section{Results}

\section{Patient and Allo-HSCT Characteristics}

Patient and transplant characteristics for all patients with AML are summarized in Table 1. One hundred and seven patients with AML underwent allo-HSCT using peripheral blood stem cells from matched related donors. The RIC regimen was applied to 63 patients $(58.8 \%)$ and the MAC regimen was applied to 44 patients $(41.2 \%)$. The median age at transplantation was 51 (23-66) years for RIC patients and 43 (20-63) years for MAC patients. The median age at transplantation was significantly higher in RIC patients compared to MAC patients ( $p=0.002)$. There was no statistically significant difference between the two groups for sex of the patients $(p=0.28)$. There was also no statistically significant difference between the two groups for

\begin{tabular}{|c|c|c|c|}
\hline Parameters & RIC & MAC & $\mathbf{p}$ \\
\hline $\mathrm{n}$ & $63(58.8 \%)$ & $44(41.2 \%)$ & - \\
\hline Sex, male/female (\%) & $32 / 31(50.7 \% / 49.3 \%)$ & $27 / 17(61.3 \% / 38.7 \%)$ & 0.28 \\
\hline Donor sex, male/female (\%) & $34 / 29(54 \% / 46 \%)$ & $30 / 14(68.2 / 31.8 \%)$ & 0.14 \\
\hline \multicolumn{3}{|c|}{ Sex combinations of patients and donors (recipient/donor) } & 0.84 \\
\hline Female/male & $17(27 \%)$ & $14(31.8 \%)$ & - \\
\hline Male/female & $14(22.2 \%)$ & $11(25.0 \%)$ & - \\
\hline Female/female & $14(22.2 \%)$ & $3(6.8 \%)$ & - \\
\hline Male/male & $18(28.6 \%)$ & $16(36.4 \%)$ & - \\
\hline Median age at transplantation (range) & $51(23-66)$ & $43(20-63)$ & 0.002 \\
\hline \multicolumn{3}{|l|}{ ECOG performance status } & $<0.001$ \\
\hline 0 & $1(1.6 \%)$ & $3(6.8 \%)$ & - \\
\hline 1 & $39(61.9 \%)$ & $41(93.2 \%)$ & - \\
\hline 2 & $23(36.5 \%)$ & 0 & - \\
\hline \multicolumn{3}{|l|}{ Cytogenetic risk group } & 0.25 \\
\hline Favorable & 0 & 0 & - \\
\hline Intermediate & $42(66.7 \%)$ & $35(79.5 \%)$ & - \\
\hline Adverse & $14(22.2 \%)$ & $5(11.4 \%)$ & - \\
\hline Missing & $7(11.1 \%)$ & $4(9.1 \%)$ & - \\
\hline Cell counts in the transplant (CD34+) & $7.5( \pm 4.0) \times 10^{6} / \mathrm{kg}$ & $9.3( \pm 5.6) \times 10^{6} / \mathrm{kg}$ & 0.06 \\
\hline \multicolumn{3}{|l|}{ CMV serologic status of the patients } & 0.52 \\
\hline CMV seropositive & $62(98.4 \%)$ & $42(95.4 \%)$ & - \\
\hline CMV seronegative & 0 & $1(2.3 \%)$ & - \\
\hline Missing & $1(1.6 \%)$ & $1(2.3 \%)$ & - \\
\hline \multicolumn{3}{|l|}{ CMV status of the donors } & 0.88 \\
\hline CMV seropositive & $54(85.7 \%)$ & $38(86.4 \%)$ & - \\
\hline CMV seronegative & $1(1.6 \%)$ & $1(2.3 \%)$ & - \\
\hline Missing & $8(12.7 \%)$ & $5(11.4 \%)$ & - \\
\hline
\end{tabular}


sex combinations of patients and donors $(p=0.84)$. The number of patients graded with ECOG performance status 0,1 , and 2 was $1(1.6 \%), 39(61.9 \%)$, and 23 (36.5\%) for RIC patients, while $3(6.8 \%)$ and $41(93.2 \%)$ MAC patients were graded with performance status 0 and 1, respectively [14]. There was a statistically significant difference between the two groups for ECOG performance status $(p<0.001)$. Patients who received the MAC regimen had better ECOG performance status than patients who received the RIC regimen. Cytogenetic analyses were present for 96 patients: 42 (66.7\%) patients were classified in the intermediate-risk group and $14(22.2 \%)$ patients were in the adverse-risk group among RIC patients, while 35 (79.5\%) patients were classified in the intermediate-risk group and $5(11.4 \%)$ patients were in the adverse-risk group for MAC patients according to the European LeukemiaNet classification [13]. There was no statistically significant difference between the two groups for karyotype analyses $(p=0.25)$. The CD34+ cell counts were $7.5( \pm 4.0) \times 106 / \mathrm{kg}$ for RIC patients and 9.3 $( \pm 5.6) \times 10^{6} / \mathrm{kg}$ for MAC patients $(p=0.06)$. Cytomegalovirus seropositivity statuses of the patients and donors were similar between the two groups receiving RIC and MAC regimens $(p=0.52)$.

The HCT-comorbidity index of patients was statistically significantly different between the two groups $(p<0.001)$. There was no statistically significant difference in terms of the disease risk index between the two groups of patients $(p=0.31)$. The disease statuses of RIC and MAC patients during transplantation were similar. Primary graft failure was not observed in those patients. A total of $22(34.9 \%)$ RIC recipients and $15(34.1 \%)$ MAC recipients died during the follow-up period $(p=0.93)$. The clinical characteristics of RIC and MAC patients are summarized in Table 2.

\section{Survival Outcomes}

The median follow-up period was 37 months (range: 6-210) for the all patients. The 6-month overall survival (OS) was 93\% in RIC patients compared to MAC patients with $82 \%$, with no

\begin{tabular}{|c|c|c|c|}
\hline Parameters & RIC & MAC & $p$ \\
\hline \multicolumn{3}{|l|}{ HSCT-comorbidity index } & $<0.001$ \\
\hline 0 & 22 (34.9\%) & 40 (90.9\%) & - \\
\hline 1 & $15(23.8 \%)$ & $4(9.1 \%)$ & - \\
\hline 2 & $24(38.1 \%)$ & 0 & - \\
\hline 3 & $2(3.2 \%)$ & 0 & - \\
\hline \multicolumn{3}{|l|}{ Disease risk index } & 0.31 \\
\hline Low & 0 & 0 & - \\
\hline Intermediate & $48(76.2 \%)$ & $31(70.5 \%)$ & - \\
\hline High & $11(17.5 \%)$ & $8(18.2 \%)$ & - \\
\hline Very high & 0 & $1(2.3 \%)$ & - \\
\hline Missing & $4(6.3 \%)$ & $4(9.1 \%)$ & - \\
\hline \multicolumn{3}{|l|}{ Disease status during transplantation } & 0.88 \\
\hline CR1 (\%) & $50(79.4 \%)$ & $32(72.7 \%)$ & - \\
\hline Subsequent CR (\%) & $10(15.9 \%)$ & $5(11.4 \%)$ & - \\
\hline Active disease $(\%)$ & $3(4.8 \%)$ & 7 (15.9\%) & - \\
\hline \multicolumn{3}{|l|}{ Complete remission } & 0.68 \\
\hline After first induction chemotherapy & $50(83.3 \%)$ & $32(86.5 \%)$ & - \\
\hline After second induction chemotherapy & $10(16.7 \%)$ & $5(13.5 \%)$ & - \\
\hline \multicolumn{3}{|l|}{ Causes of death } & 0.05 \\
\hline Relapse & $17(77.3 \%)$ & $8(53.3 \%)$ & - \\
\hline Infection & $5(22.7 \%)$ & $5(33.3 \%)$ & - \\
\hline GVHD & 0 & $1(6.7 \%)$ & - \\
\hline Heart attack & 0 & $1(6.7 \%)$ & - \\
\hline Mortality & $22 / 63(34.9 \%)$ & $15 / 44(34.1 \%)$ & 0.93 \\
\hline Relapse incidence & $17 / 63(27 \%)$ & $8 / 44(18.2 \%)$ & 0.49 \\
\hline Median time from allo-HSCT to relapse (range) months & $6(0.7-37.8)$ & $3.5(1.0-18.9)$ & 0.19 \\
\hline Non-relapse mortality & $5 / 63,7.9 \%$ & $8 / 44,18.1 \%$ & 0.027 \\
\hline
\end{tabular}


statistically significant difference. The 3-year OS for RIC and MAC patients was $67 \%$ and $60 \%$, respectively $(p=0.22)$. The 5 -year OS rates for RIC and MAC patients were both $60 \%$. The OS for RIC patients was $135 \pm 12$ versus $88 \pm 13.0$ months for MAC patients with no statistically significant difference, as shown in Figure $1(p=0.29)$.

The 3-year PFS for RIC and MAC patients was $88 \%$ and $77 \%$. The type of conditioning regimen did not influence 3-year PFS $(p=0.24)$. The 5 -year PFS for RIC and MAC patients was $59 \%$ and $59 \%$, respectively. The PFS for RIC patients was different from the PFS for MAC patients ( $130 \pm 12$ versus $96 \pm 12$ months), but no statistically significant difference was observed, as shown in Figure $2(p=0.78)$.

\section{Non-relapse Mortality}

Non-relapse mortality (NRM) was more frequent in the MAC patients than RIC patients $(7 / 44,15.9 \%$ vs. $5 / 63,7.9 \%$, $p=0.027$ ). The major causes of NRM were infections ( 5 vs. 5 ), GVHD ( 1 vs. 0 ), and heart attack ( 1 vs. 0 ) in the MAC and RIC patients, respectively. The cumulative relapse incidence was not statistically significantly different between RIC and MAC patients ( $p=0.49$ ) (Figure 3 ).

\section{Acute and Chronic GVHD}

Nine of the RIC patients (14.3\%) and 9 of the MAC patients (20.5\%) developed acute GVHD. Sixteen of the RIC patients (25.4\%) and 8 of the MAC patients (18.2\%) developed chronic GVHD. There was no statistically significant difference between the RIC and MAC patients in terms of acute $(p=0.40)$ and chronic GVHD ( $p=0.37)$. The cumulative incidence rates of acute $(p=0.22)$ and chronic GVHD $(p=0.79)$ in the RIC and MAC groups

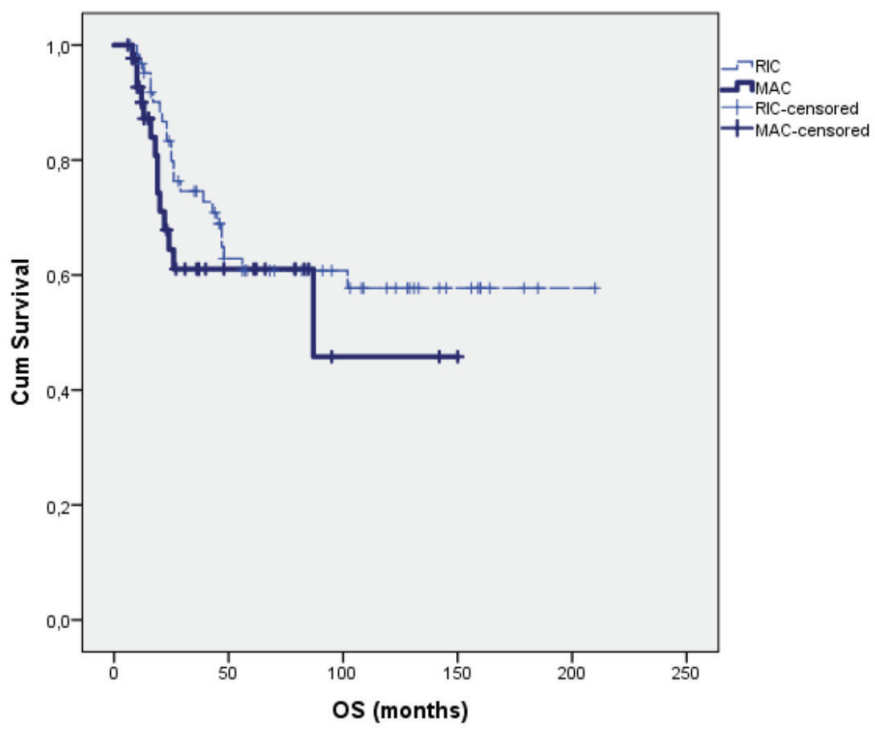

Figure 1. The overall survival for RIC and MAC patients ( $p=0.29$ ).

OS: Overall survival, RIC: reduced-intensity conditioning, MAC: myeloablative conditioning. did not differ to a statistically significant extent (Figures 4 and 5; Table 3).

\section{Cox Regression Analysis}

In univariate analyses the parameters that affected OS were development of chronic GVHD ( $p=0.04)$ and CD34+ counts $(p<0.001)$, as shown in Table 4. Cox regression analysis revealed CD34+ cell counts and development of chronic GVHD as parameters to predict $\mathrm{OS}$.

In univariate analyses the parameters that affected PFS were cytogenetics of the patients $(p=0.08)$, disease risk index $(p=0.006)$, and HCT-comorbidity index of the patients $(p=0.10)$, as shown in Table 4. However, Cox regression analysis revealed no parameters to predict PFS.

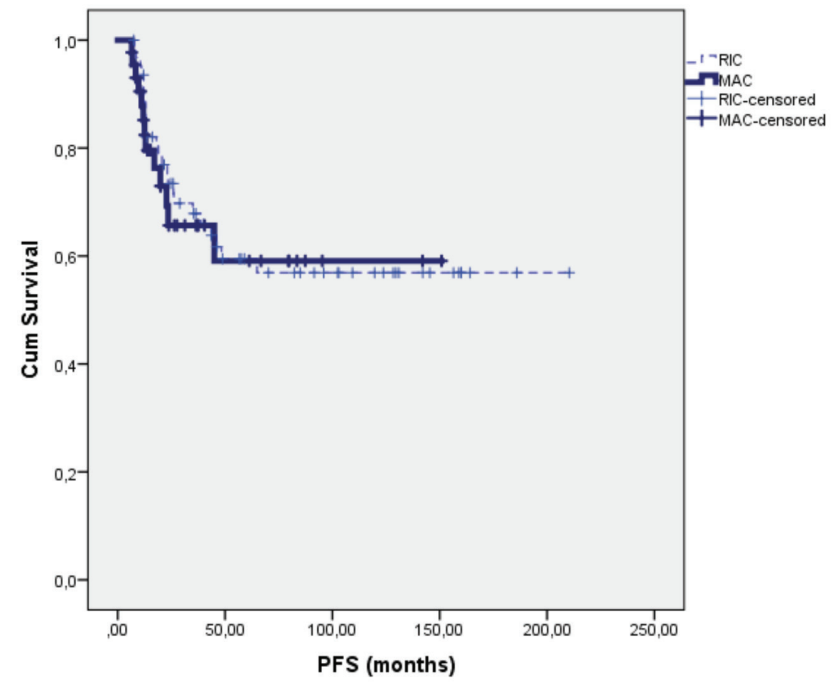

Figure 2. The progression-free survival for RIC and MAC patients $(\mathrm{p}=0.78)$.

PFS: Progression-free survival, RIC: reduced-intensity conditioning, MAC: myeloablative conditioning.

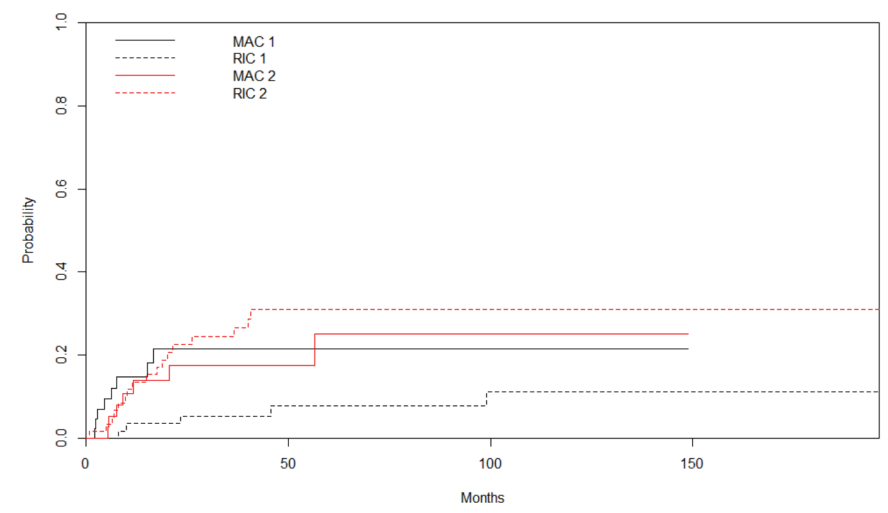

Figure 3. Cumulative incidence of non-relapse mortality for reduced-intensity conditioning (RIC) and myeloablative conditioning (MAC) regimens (MAC 1 and RIC 1) ( $p=0.027)$ and cumulative incidence of relapse for RIC and MAC regimens (MAC 2 and RIC 2) $(\mathrm{p}=0.496)$.

RIC: Reduced-intensity conditioning, MAC: myeloablative conditioning. 


\section{Discussion}

Allo-HSCT is an effective treatment modality for several malignant and non-malignant hematologic disorders [1]. The intensity of conditioning regimens can vary substantially. When selecting the right conditioning regimen for AML patients, disease-related factors such as diagnosis and remission status and patient-related factors including age, donor availability, and presence of comorbid conditions are the parameters to be considered [20].

Recently a randomized study was performed in patients with AML or MDS in remission comparing RIC conditioning to MAC conditioning and using related or unrelated donor grafts. The

\begin{tabular}{|c|c|c|c|}
\hline & RIC, n (\%) & MAC, n (\%) & $\mathbf{p}$ \\
\hline Grade 1 & $6(9.5 \%)$ & $3(6.8 \%)$ & \multirow[b]{2}{*}{0.40} \\
\hline Grade 2 & $2(3.2 \%)$ & $4(9.1 \%)$ & \\
\hline Chronic GVHD, n (\%) & $16(25.4 \%)$ & $8(18.2 \%)$ & \multirow{3}{*}{0.37} \\
\hline Limited & $10(15.9 \%)$ & $7(15.9 \%)$ & \\
\hline Extensive & $6(9.5 \%)$ & $1(2.3 \%)$ & \\
\hline
\end{tabular}

\begin{tabular}{|c|c|c|c|c|c|c|}
\hline \multirow[b]{2}{*}{ Parameters for OS } & \multicolumn{3}{|c|}{ Univariate analysis } & \multicolumn{3}{|c|}{ Multivariate analysis } \\
\hline & $\begin{array}{l}\text { Hazard } \\
\text { ratio }\end{array}$ & $\begin{array}{l}\text { 95\% confidence } \\
\text { interval }\end{array}$ & $\mathbf{p}$ & $\begin{array}{l}\text { Hazard } \\
\text { ratio }\end{array}$ & $\begin{array}{l}\text { 95\% confidence } \\
\text { interval }\end{array}$ & $\mathbf{p}$ \\
\hline Age (years) & 0.993 & $0.973-1.014$ & 0.50 & - & - & - \\
\hline Sex (male/female) & 1.044 & $0.644-1.693$ & 0.86 & - & - & - \\
\hline Cytogenetic & 0.786 & $0.526-1.175$ & 0.24 & - & - & - \\
\hline ECOG PS & 0.802 & $0.474-1.355$ & 0.40 & - & - & - \\
\hline Conditioning regimen & 0.358 & $0.214-0.601$ & 0.29 & - & - & - \\
\hline Acute GVHD & 1.047 & $0.531-2.065$ & 0.89 & - & - & - \\
\hline Chronic GVHD & 1.798 & $1.004-3.221$ & 0.04 & 0.502 & $0.279-0.905$ & 0.02 \\
\hline CMV serologic status & 0.489 & $0.080-3.006$ & 0.44 & - & - & - \\
\hline HSCT-comorbidity index & 0.940 & $0.707-1.250$ & 0.67 & - & - & - \\
\hline Disease risk index & 0.828 & $0.548-1.251$ & 0.36 & - & - & - \\
\hline Cell counts in the transplant (CD34+) & 1.127 & $1.065-1.193$ & $<0.001$ & 1.133 & $1.072-1.197$ & $<0.001$ \\
\hline \multicolumn{7}{|l|}{ Parameters for PFS } \\
\hline Age (years) & 1.002 & $0.970-1.034$ & 0.91 & - & - & - \\
\hline Sex (male/female) & 1.049 & $0.707-1.558$ & 0.81 & - & - & - \\
\hline Cytogenetic & 1.503 & $0.939-2.404$ & 0.08 & 1.391 & $0.702-2.755$ & 0.34 \\
\hline ECOG PS & 1.210 & $0.550-2.661$ & 0.63 & - & - & - \\
\hline Conditioning regimen & 1.060 & $0.455-2.466$ & 0.78 & - & - & - \\
\hline Acute GVHD & 1.504 & $0.450-5.028$ & 0.50 & - & - & - \\
\hline Chronic GVHD & 1.122 & $0.448-2.813$ & 0.80 & - & - & - \\
\hline CMV serologic status & 1.286 & $0.442-3.738$ & 0.64 & - & - & - \\
\hline HSCT-comorbidity index & 1.412 & $0.928-2.150$ & 0.10 & 1.394 & $0.866-2.246$ & 0.17 \\
\hline Diseases risk index & 1.242 & $0.733-2.106$ & 0.006 & 1.073 & $0.490-2.354$ & 0.86 \\
\hline Cell counts in the transplant (CD34+) & 1.039 & $0.951-1.134$ & 0.39 & - & - & - \\
\hline
\end{tabular}


trial closed with 272 enrolled patients due to excess relapse in the RIC arm. RIC was associated with more relapse, lower NRM, lower relapse-free survival, and, in the AML subgroup, lower OS. The conclusion of the study was that MAC conditioning should be the standard of care for fit patients with AML or MDS [12].

Choosing the proper conditioning remains challenging, given the need to balance the risk of relapse with the risk of transplantation-related mortality. The main finding of our study

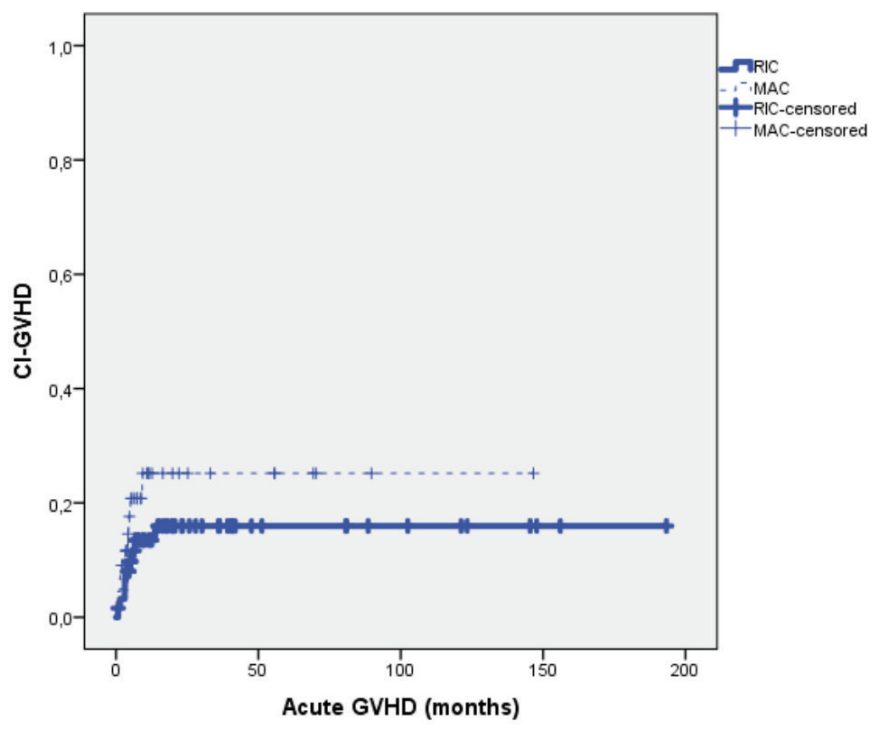

Figure 4. Cumulative incidence plot of acute graft-versus-host disease for reduced-intensity conditioning and myeloablative conditioning regimens $(p=0.22)$.

GVHD: Graft-versus-host disease, Cl: cumulative incidence, RIC: reduced-intensity conditioning, MAC: myeloablative conditioning.

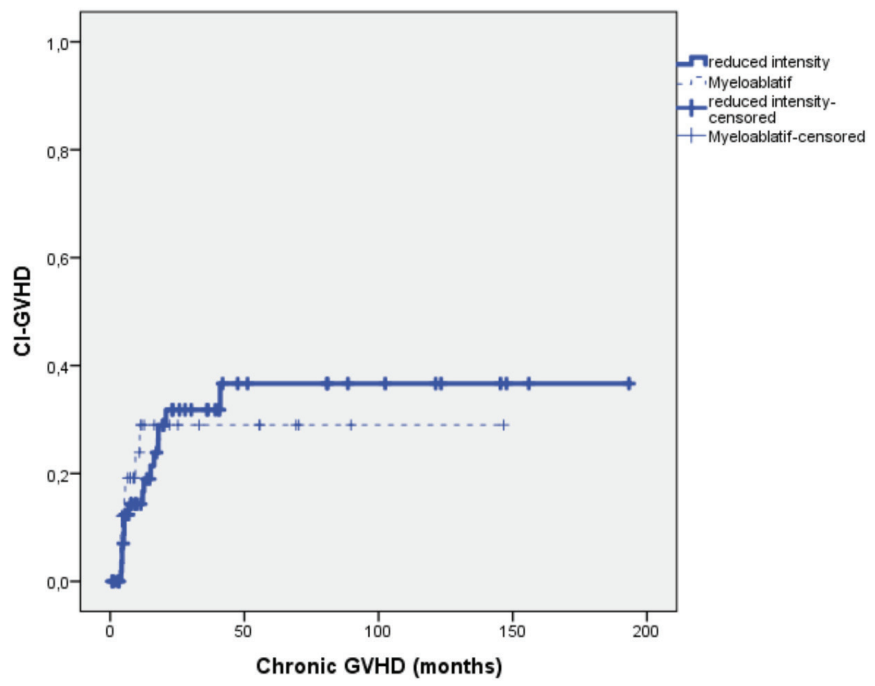

Figure 5. Cumulative incidence plot of chronic graft-versus-host disease for reduced-intensity conditioning and myeloablative conditioning regimens $(p=0.79)$.

GVHD: Graft-versus-host disease, Cl: cumulative incidence. was that RIC and MAC yielded similar outcomes (OS and PFS), even though patients in the RIC arm were somewhat older.

The European Group for Blood and Marrow Transplantation analyzed survival outcomes of patients with $\mathrm{AML}$ older than 50 years treated with HLA-matched sibling allo-HSCT after RIC or MAC regimens. Despite the older age of the RIC patients, grade 2-4 acute GVHD and transplant-related mortality were significantly lower after the RIC regimen. However, there was no statistically significant difference in OS and PFS for patients receiving either the MAC or the RIC regimen, regardless of the status of the disease at the time of transplantation [21]. Goker et al. [22] compared survival outcomes of patients transplanted with RIC versus MAC regimens. They showed that the MAC regimen was associated with lower OS and PFS. Additionally, they showed an apparent favorable effect of the RIC regimen as a lower acute GVHD rate. On the other hand, it had a higher rate of chronic GVHD.

GVHD and relapses remain major causes of mortality during HSCT $[23,24]$. The RIC regimen caused less tissue damage and lower levels of inflammatory cytokines, which may explain the lower incidence of severe GVHD following RIC conditioning $[23,25,26,27]$. It has been demonstrated that the incidence of acute GVHD was related to the intensity of the conditioning regimen. RIC, which consists of total body irradiation (2Gy) with or without fludarabine, was reported to reduce the incidence of severe acute GVHD compared with MAC [27]. Cutler et al. [28] showed that allogeneic peripheral blood stem cell transplantation was associated with a greater degree of acute and chronic GVHD than bone marrow transplantation and this may be related to lower rates of relapse. Peripheral blood grafts were used for all allo-HSCT procedures in our patients. This study showed that the incidence of acute and chronic GVHD was similar between RIC and MAC regimen groups. Reported incidence rates range from $9 \%$ to $50 \%$ in patients who receive allo-HSCT from a genotypically HLAidentical sibling $[29,30]$. We followed our patients closely and made sure that they used their immunosuppressive drugs regularly. Therefore, this study may show a lower rate of GVHD. Future studies will reveal the cause of chronic GVHD seen to be lower in MAC regimens than in RIC regimens in this study.

\section{Conclusion}

In this retrospective evaluation, RIC allo-HSCT outcomes were similar when compared to the MAC allo-HSCT outcomes in our patients with AML. MAC and RIC regimens were similar in terms of OS and PFS in AML patients with allo-HSCT. The incidence of acute and chronic GVHD was also similar between the two groups. NRM was more frequent in the MAC patients than RIC patients. Relapse rate was similar between the RIC and MAC 
patients. This study has some limitations. First of all, the study was retrospective. There were imbalances between the patient populations, which is known as a weakness of this type of retrospective study. Local standards also changed from 2001 to 2017. Therefore, spanning a long time period was a limitation of this study. In conclusion, the conditioning regimen should be tailored and chosen based on the disease and individual patient characteristics. Future powerful randomized clinical trials could further elucidate the type of conditioning to be used and tailored on a per patient basis.

\section{Ethics}

Ethics Committee Approval: All of the ethical considerations were strictly followed in accordance with the 1964 Helsinki Declaration in the Hacettepe University Faculty of Medicine. As standard care/action of the hospitals of the Hacettepe University Faculty of Medicine, it has been recognized from the patient records that all of the studied patients gave informed consent at the time of admission to the hospital and before the administration of chemotherapy and other relevant diagnostic/ therapeutic standards of care.

Informed Consent: All of the studied patients gave informed consent at the time of admission to the hospital.

\section{Authorship Contributions}

Surgical and Medical Practices: R.Ç.; Concept: H.G., N.S.; Design: H.D.; Data Collection or Processing: E.A., F.T.; Analysis or Interpretation: Y.B., O.Ö., Literature Search: I.C.H., S.A.; Writing: R.Ç.

Conflict of Interest: The authors of this paper have no conflicts of interest, including specific financial interests, relationships, and/or affiliations relevant to the subject matter or materials included.

\section{References}

1. Santos GW, Tutschka PJ, Brookmeyer R, Saral R, Beschorner WE, Bias WB, Braine HG, Burns WH, Elfenbein GJ, Kaizer H, Mellits D, Sensenbrenner LL, Stuart RK, Yeager AM. Marrow transplantation for acute nonlymphocytic leukemia after treatment with busulfan and cyclophosphamide. N Engl J Med 1983;309:1347-1353.

2. Lowenberg B, Downing JR, Burnett A. Acute myeloid leukemia. N Engl J Med 1999;341:1051-1062.

3. Rowe JM, Tallman MS. Intensifying induction therapy in acute myeloid leukemia: has a new standard of care emerged? Blood 1997;90:2121-2126.

4. Leith CP, Kopecky KJ, Chen IM, Eijdems L, Slovak ML, McConnell TS, Head DR, Weick J, Grever MR, Appelbaum FR, Willman CL. Frequency and clinical significance of the expression of the multidrug resistance proteins MDR1/ P-glycoprotein, MRP1, and LRP in acute myeloid leukemia. A Southwest Oncology Group Study. Blood 1999;94:1086-1099.

5. Sorror ML, Maris MB, Storb R, Baron F, Sandmaier BM, Maloney DG, Storer B. Hematopoietic cell transplantation (HCT)-specific comorbidity index: a new tool for risk assessment before allogeneic HCT. Blood 2005;106:29122919.
6. Wahid SF. Indications and outcomes of reduced-toxicity hematopoietic stem cell transplantation in adult patients with hematological malignancies. Int J Hematol 2013;97:581-598.

7. Cornelissen JJ, Gratwohl A, Schlenk RF, Sierra J, Bornhäuser M, Juliusson G, Råcil Z, Rowe JM, Russell N, Mohty M, Löwenberg B, Socié G, Niederwieser D, Ossenkoppele GJ. The European LeukemiaNet AML Working Party consensus statement on allogeneic HSCT for patients with AML in remission: an integrated-risk adapted approach. Nat Rev Clin Oncol 2012;9:579.

8. Horwitz ME. Reduced intensity versus myeloablative allogeneic stem cell transplantation for the treatment of acute myeloid leukemia, myelodysplastic syndrome and acute lymphoid leukemia. Curr Opin Oncol 2011;23:197-202.

9. Pidala J, Kim J, Anasetti C, Kharfan-Dabaja MA, Nishihori T, Field T, Perkins J, Perez L, Fernandez HF. Pharmacokinetic targeting of intravenous busulfan reduces conditioning regimen related toxicity following allogeneic hematopoietic cell transplantation for acute myelogenous leukemia. J Hematol Oncol 2010;3:36.

10. Bornhäuser $M$, Kienast J, Trenschel R, Burchert A, Hegenbart U, Stadler $M$, Baurmann $H$, Schäfer-Eckart $K$, Holler $E$, Kröger $N$, Schmid $C$, Einsele $H$, Kiehl MG, Hiddemann W, Schwerdtfeger R, Buchholz S, Dreger P, Neubauer A, Berdel WE, Ehninger G, Beelen DW, Schetelig J, Stelljes M. Reducedintensity conditioning versus standard conditioning before allogeneic haemopoietic cell transplantation in patients with acute myeloid leukaemia in first complete remission: a prospective, open-label randomised phase 3 trial. Lancet Oncol 2012;13:1035-1044.

11. Scott BL, Pasquini MC, Logan B, Wu J, Devine $S$, Porter DL, Maziarz RT, Warlick E, Fernandez HF, Alyea EP, Hamadani M, Bashey A, Giralt SA, Leifer E, Geller N, Le-Rademacher J, Mendizabal AM, Horowitz MM, Deeg HJ, Horwitz ME. Results of a phase III randomized, multi-center study of allogeneic stem cell transplantation after high versus reduced intensity conditioning in patients with myelodysplastic syndrome (MDS) or acute myeloid leukemia (AML): Blood and Marrow Transplant Clinical Trials Network (BMT CTN) 0901. Blood 2015;126:8.

12. Scott BL, Pasquini MC, Logan BR, Wu J, Devine SM, Porter DL, Maziarz RT, Warlick ED, Fernandez HF, Alyea EP, Hamadani M, Bashey A, Giralt S, Geller $\mathrm{NL}$, Leifer E, Le-Rademacher J, Mendizabal AM, Horowitz MM, Deeg HJ, Horwitz ME. Myeloablative versus reduced-intensity hematopoietic cell transplantation for acute myeloid leukemia and myelodysplastic syndromes. J Clin Oncol 2017;35:1154-1161.

13. Döhner H, Estey E, Grimwade $D$, Amadori $S$, Appelbaum FR, Büchner $T$, Dombret $H$, Ebert BL, Fenaux P, Larson RA, Levine RL, Lo-Coco F, Naoe T, Niederwieser D, Ossenkoppele GJ, Sanz M, Sierra J, Tallman MS, Tien HF, Wei AH, Löwenberg B, Bloomfield CD. Diagnosis and management of AML in adults: 2017 ELN recommendations from an international expert panel. Blood 2017;129:424-447.

14. Oken MM, Creech RH, Tormey DC, Horton J, Davis TE, McFadden ET, Carbone PP. Toxicity and response criteria of the Eastern Cooperative Oncology Group. Am J Clin Oncol 1982;5:649-656.

15. Giralt S, Ballen K, Rizzo D, Bacigalupo A, Horowitz M, Pasquini M, Sandmaier B. Reduced-intensity conditioning regimen workshop: defining the dose spectrum. Report of a workshop convened by the Center for International Blood and Marrow Transplant Research. Biol Blood Marrow Transplant 2009;15:367-369.

16. Bacigalupo A, Ballen K, Rizzo D, Giralt S, Lazarus H, Ho V, Apperley J, Slavin S, Pasquini M, Sandmaier BM, Barrett J, Blaise D, Lowski R, Horowitz M. Defining the intensity of conditioning regimens: working definitions. Biol Blood Marrow Transplant 2009;15:1628-1633.

17. Khouri IF, Przepiorka D, van Besien K, O'Brien S, Palmer JL, Lerner $S$, Mehra RC, Vriesendorp HM, Andersson BS, Giralt S, Körbling M, Keating MJ, Champlin RE. Allogeneic blood or marrow transplantation for chronic lymphocytic leukaemia: timing of transplantation and potential effect of fludarabine on acute graft-versus-host disease. Br J Haematol 1997;97:466-473. 
18. Gratwohl A, Hermans J, Niederwieser D, van Biezen A, van Houwelingen HC, Apperley J; Chronic Leukemia Working Party of the European Group for Blood and Marrow Transplantation EBMT. Female donors influence transplant-related mortality and relapse incidence in male recipients of sibling blood and marrow transplants. Hematol J 2001;2:363-370.

19. R Core Team. A Language and Environment for Statistical Computing. Vienna, R Foundation for Statistical Computing, 2015.

20. Gyurkocza B, Sandmaier BM. Conditioning regimens for hematopoietic cell transplantation: one size does not fit all. Blood 2014;124:344-353.

21. Aoudjhane M, Labopin M, Gorin NC, Shimoni A, Ruutu T, Kolb HJ, Frassoni F, Boiron JM, Yin JL, Finke J, Shouten H, Blaise D, Falda M, Fauser AA, Esteve J, Polge E, Slavin S, Niederwieser D, Nagler A, Rocha V; Acute Leukemia Working Party (ALWP) of the European group for Blood and Marrow Transplantation (EBMT). Comparative outcome of reduced intensity and myeloablative conditioning regimen in HLA identical sibling allogeneic haematopoietic stem cell transplantation for patients older than 50 years of age with acute myeloblastic leukaemia: a retrospective survey from the Acute Leukemia Working Party (ALWP) of the European group for Blood and Marrow Transplantation (EBMT). Leukemia 2005;19:2304-2312.

22. Goker H, Ozdemir E, Uz B, Buyukasik Y, Turgut M, Serefhanoglu S, Aksu S, Sayinalp N, Haznedaroglu IC, Tekin F, Karacan Y, Unal S, Eliacik E, Isik A, Ozcebe Ol. Comparative outcome of reduced intensity and myeloablative conditioning regimen in HLA identical sibling allogeneic hematopoietic stem cell transplantation for acute leukemia patients: a single center experience. Transfus Apher Sci 2013;49:590-599.

23. Ferrara JL, Cooke KR, Pan L, Krenger W. The immunopathophysiology of acute graft-versus-host-disease. Stem Cells 1996;14:473-489.

24. Harris AC, Ferrara JL, Levine JE. Advances in predicting acute GVHD. Br J Haematol 2013;160:288-302.
25. Goker H, Haznedaroglu IC, Chao NJ. Acute graft-vs-host disease: pathobiology and management. Exp Hematol 2001;29:259-277.

26. Pérez-Simón JA, Díez-Campelo $M$, Martino $R$, Brunet $S$, Urbano $A$, Caballero $M D$, de León $A$, Valcárcel $D$, Carreras E, del Cañizo MC, López-Fidalgo J, Sierra J, San Miguel JF. Influence of the intensity of the conditioning regimen on the characteristics of acute and chronic graft-versus-host disease after allogeneic transplantation. Br J Haematol 2005;130:394-403.

27. Mielcarek M, Martin PJ, Leisenring W, Flowers ME, Maloney DG, Sandmaier BM, Maris MB, Storb R. Graft-versus-host disease after nonmyeloablative versus conventional hematopoietic stem cell transplantation. Blood 2003;102:756-762.

28. Cutler C, Giri S, Jeyapalan S, Paniagua D, Viswanathan A, Antin JH. Acute and chronic graft-versus-host disease after allogeneic peripheral-blood stem-cell and bone marrow transplantation: a meta-analysis. J Clin Oncol 2001;19:3685-3691.

29. Filipovich AH, Weisdorf D, Pavletic S, Socie G, Wingard JR, Lee SJ, Martin P, Chien J, Przepiorka D, Couriel D, Cowen EW, Dinndorf P, Farrell A, Hartzman R, Henslee-Downey J, Jacobsohn D, McDonald G, Mittleman B, Rizzo JD, Robinson M, Schubert M, Schultz K, Shulman H, Turner M, Vogelsang G, Flowers ME. National Institutes of Health consensus development project on criteria for clinical trials in chronic graft-versus-host disease: I. Diagnosis and staging working group report. Biol Blood Marrow Transplant 2005;11:945-956.

30. Jagasia $M$, Arora $M$, Flowers $M E$, Chao NJ, McCarthy PL, Cutler CS, UrbanoIspizua A, Pavletic SZ, Haagenson MD, Zhang MJ, Antin JH, Bolwell BJ, Bredeson C, Cahn JY, Cairo M, Gale RP, Gupta V, Lee SJ, Litzow M, Weisdorf DJ, Horowitz MM, Hahn T. Risk factors for acute GVHD and survival after hematopoietic cell transplantation. Blood 2012;119:296-307. 